\title{
Formulation, Preparation and Evaluation of Low-Cost Extrude Products Based on Cereals and Pulses
}

\author{
Mohammad Reza Shadan', Kavita Waghray², Fahimeh Khoushabi ${ }^{3}$ \\ ${ }^{1}$ Department of Biochemistry, Osmania University, Hyderabad, India \\ ${ }^{2}$ Department of Food Technology, University College of Technology Osmania University, Hyderabad, India \\ ${ }^{3}$ School of Health, University of Medical Sciences and Health Services, Zabol, Iran \\ Email: shadan4000@yahoo.com
}

Received 18 May 2014; revised 23 June 2014; accepted 10 July 2014

Copyright (C) 2014 by authors and Scientific Research Publishing Inc.

This work is licensed under the Creative Commons Attribution International License (CC BY). http://creativecommons.org/licenses/by/4.0/

(c) (i) Open Access

\section{Abstract}

Protein-energy malnutrition among children is the major health challenges and it may be related to low nutritional quality of traditional complementary foods and high cost of quality proteinbased complementary foods. The aim of this study was formulation, preparation and evaluation of low-cost extruded products based on cereals and pulses. Composite flours were prepared using cereals and pulses, then formulated and extruded by a twin screw extruder in Osmania University, Hyderabad, India. Data were analyzed by SPSS software. Results showed: the protein contents of extruded formulas B, D and F were in the highest values. Carbohydrate in the extruded formula A was significantly higher than others. The lowest amount of ash and crude fiber were observed in the formula A. Content of energy in the extruded formulas E, F and C was higher; mean (SD) of Fe content in the extruded formula $B, D$ and $F$ was in the higher ranks among others. Calcium content in the extruded formulas $\mathrm{C}, \mathrm{E}$ and $\mathrm{F}$ was in the highest amounts. Magnesium content in the extruded formulas B, D and F was higher than others. Cu content in the extruded formula C, D, B and $F$ was higher than others. Manganese content in the extruded formulas $B, C$ and $F$, and zinc content in the formulas B, D and F were higher than others. Tap density showed the lowest amount in the formula B, D and F, while their bulk density was higher. WHC was in the highest amount in the extruded formula A, while WSI in the extruded formula B, D and followed by F was in the highest amount. The mean scores of sensory evaluation of extruded products $F$ showed that this combination has significantly better colour, flavour, texture and overall acceptability than others.

\section{Keywords}

Low Cost, Extruded Products, Cereals, Pulses

How to cite this paper: Shadan, M.R., Waghray, K. and Khoushabi, F. (2014) Formulation, Preparation and Evaluation of Low-Cost Extrude Products Based on Cereals and Pulses. Food and Nutrition Sciences, 5, 1333-1340. 


\section{Introduction}

The World Health Organization defines nutrition as "a process whereby living organisms utilize food for maintenance of life, growth and normal function of organs and tissues and the production of energy" [1].

Protein-energy malnutrition among children is the major health challenges in developing countries [2] [3]. This nutrition problem is ascribed to the inappropriate complementary feeding practices, low nutritional quality of traditional complementary foods and high cost of quality protein-based complementary foods [4]-[10]. It is evidence that high prevalence of deaths each year among children aged less than five years old in the developing world is associated with malnutrition [3]. The interaction of poverty, poor health and poor complementary feeding practices has a multiplier effect on the general welfare of the children population and also contributes significantly towards growth retardation, poor cognitive development, illness and death amongst children in developing countries [11] [12]. It is well known that high cost of fortified nutritious proprietary complementary foods in many parts of developing countries is always beyond the reach of most families [13]; hence many families depend on inadequately processed and low-quality traditional complementary foods to wean their children.

As cereals and pulses play a predominant role in diets of developing countries, beyond, the nutritional problem is associated with traditional complementary foods, however in the present study, we decided to formulate complementary foods from cereals (rice, maize) and pulses. The use of cereal, pulse, and based food has long been advocated as alternative protein and energy source for infant and young children food products.

In current research, researchers used different methods of processing such as soaking, germination, milling, and finally extrusion cooking to increasing shelf-life; removal of toxins; removal of anti-nutrients, which will improve digestibility and availability of nutrients; and improvement of palatability of new products.

Extrusion is a powerful food-processing operation which utilizes high temperature and high shear force to produce a product with unique physical and chemical characteristics. Extruded products are mainly produced from cereal grain. However, cereal-based snacks are usually low in nutritive density, especially in protein content and essential amino acids [14]. Snack products, which contain mainly carbohydrate and fat, can be made with increased protein content by adding high quality protein including pulses (such as cowpea and chickpea and red gram). Extrusion cooking is used worldwide to produce snack foods, ready-to-eat cereals, baby foods, pasta and pet foods [15].

The main aim of this study was formulation, preparation and evaluation of low-cost extrude products based on cereals and pulses.

\section{Materials and Methods}

\subsection{Preparation (Blend Preparation and Mixing)}

Composite of products was prepared by mixing corn flour, rice flour and germinated or not germinated of cow pea flour, chickpea flour and green gram flour in the different ratios on a dry-to-dry weight basis, shown in the Table 1. These blends were chosen according to preliminary tests without jamming of extruder and for acceptable product's physical characteristics as well as better nutritive value in the final product. The blended samples were conditioned to $21 \%-22 \%$ moisture by spraying with a calculated amount of water and mixing continuously at medium speed in a blender. The samples were put in buckets and stored at $4{ }^{\circ} \mathrm{C}$ overnight. The feed material was then allowed to stay for $3 \mathrm{~h}$ to equilibrate at room temperature prior to extrusion.

\subsection{Extruder}

A co-rotating twin-screw extruder (Basic Technology Pvt. Ltd., Kolkata, India) with three zones (feeding zone, cooking zone, and die zone) was used to process the different formulation.

The die diameter was selected at $1.8 \mathrm{~mm}$ as recommended by the manufacturer for such product and recommended by [9].

The product was collected at the die end and kept at $60^{\circ} \mathrm{C} \pm 0.5^{\circ} \mathrm{C}$ in an incubator for $12 \mathrm{~h}$ duration to remove extra moisture from the product. The samples were packed in polythene bags for further analysis. Three replicate samples were extruded.

\subsection{Chemical Composition}

Moisture, ash, fat, protein and mineral contents (namely $\mathrm{Mg}, \mathrm{Ca}, \mathrm{Fe}, \mathrm{Mn}, \mathrm{Cu}$ and $\mathrm{Zn}$ ) measured by using stan- 
Table 1. Formulation of different composite flours (based on cereals and pulses).

\begin{tabular}{|c|c|c|c|c|c|c|}
\hline Ingredients/Supplementary & A & B & $\mathrm{C}$ & $\mathrm{D}$ & $\mathrm{E}$ & $\mathrm{F}$ \\
\hline Corn & 1000 & 550 & 550 & 550 & 550 & 550 \\
\hline Rice & 0 & 100 & 100 & 100 & 100 & 100 \\
\hline Cowpea $(\mathrm{G})^{*}$ & 0 & 300 & 0 & 250 & 0 & 100 \\
\hline Chickpea $(G)^{*}$ & 0 & 0 & 300 & 0 & 250 & 100 \\
\hline Green Gram (UG) & 0 & 50 & 50 & 0 & 0 & 50 \\
\hline Cowpea (UG) ${ }^{* *}$ & 0 & 0 & 0 & 100 & 0 & 50 \\
\hline Chickpea (UG) ${ }^{* *}$ & 0 & 0 & 0 & 0 & 100 & 50 \\
\hline Two-Mix ${ }^{* * *}$ & 12 & 12 & 12 & 12 & 12 & 12 \\
\hline Total & 1012 & 1012 & 1012 & 1012 & 1012 & 1012 \\
\hline
\end{tabular}

$(\mathbf{G})^{*}=$ Germinated, $(\mathbf{U G})^{* *}=$ Un-germinated, Two-Mix ${ }^{* * *}=$ (Edible Salt $-7 \mathrm{~g}+$ Black Pepper Powder $\left.-5 \mathrm{~g}\right), \mathbf{A}=$ Control (Only Corn), $\mathbf{B}=$ Corn + Rice + Cowpea $(G)^{*}+$ Green Gram (UG) ${ }^{* *}, \mathbf{C}=$ Corn + Rice + Chickpea $(G)^{*}+$ Green Gram $(\mathrm{UG})^{* * *}, \mathbf{D}=$ Corn + Rice + Cowpea $(\mathrm{G})^{* *}+$ Cowpea

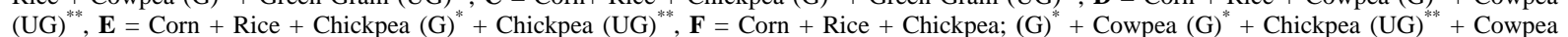
$(\mathrm{UG})^{* *}+$ Green Gram (UG) ${ }^{* *}$; Significant at $5 \%$ level; Note: Different superscript in columns indicate significant different at $5 \%$ level as shown by post hoc Bonferroni.

dard methods described by AOAC [10] [16] [17]. Dietary fibre determined by the method of Udo and Ogunwele [11] [18]. The total proportion of carbohydrate in the sample was obtained by calculation using the percentage weight method that described by James [12]. That is by subtracting the \% sum of food nutrients:

$\%$ protein, $\%$ lipids, $\%$ dietary fiber and $\%$ ash from $100 \%$. This is done by using the equation below:

$\% \mathrm{CHO}=100 \%-(\%$ protein $+\%$ lipid $+\%$ fiber $+\%$ ash $)$.

\subsection{Functional Properties}

The dried samples were analysed for the density of extrudates (including: tap density, true density and bulk density, water absorption index and water solubility index).

\subsubsection{Density of Extrudates}

This indicates the overall expansion and the changes in cell structure, pores and voids developed in the extrudates as the effect of processing as well as raw material parameters [13] [18].

\section{- Tap density}

The extrudates after grinding was filled up to $20 \mathrm{ml}$ in measuring cylinder of capacity $50 \mathrm{ml}$ and tapped 5 - 10 times. The weight of this $20 \mathrm{ml}$ of extrudates sample was taken [18].

$$
\text { Tap density }\left(\mathrm{gm} \cdot \mathrm{cc}^{-1}\right)=\frac{\text { Weight of } 20 \mathrm{ml} \text { sample }}{\text { Volume of the sample }(20 \mathrm{ml})}
$$

\section{- True density}

It was calculated by filling approximately $1 \mathrm{gm}$ of ground sample of extrudates in a burette containing toluene. Then the raise in toluene level was measured and the average of the three readings of true density was calculated [13] [18].

\section{- Bulk density (BD)}

$$
\text { True density }=\frac{\text { Weight of ground sample of extrudate }}{\text { Rise in toluene level }}
$$

As the average diameter and average length of 25 readings of extrudates sample were known, its volume was computed as [13] [18]:

$$
\mathrm{Vol} \cdot\left(\mathrm{cm}^{3}\right)=\pi \mathrm{d}^{2} \mathrm{~L} \cdot 4^{-1}
$$

where $\mathrm{d}=$ average diameter of extrudates; $\mathrm{L}=$ average specific length of extrudates in $\mathrm{cm}$.

After calculating the volume of extrudates its bulk density is obtained as:

$$
\mathrm{BD}\left(\mathrm{kg} \cdot \mathrm{cm}^{-3}\right)=\frac{\text { Mass of extrudates }(\mathrm{kg})}{\text { Volume of extrudates }\left(\mathrm{cm}^{3}\right)}
$$




\subsubsection{Water Absorption Index (WAI) and Water Solubility Index (WSI)}

WAI and WSI were determined by method suggested by Anderson [19]. The extrudate puffs were milled to mean particle size of $200-250 \mu \mathrm{m}$. A $2.5 \mathrm{~g}$ sample was dispersed in $25 \mathrm{~g}$ distilled water, using a glass rod to break up any lumps and then stirred for $30 \mathrm{~min}$. The dispersion was rinsed in tarred centrifuge tubes, made up to $32.5 \mathrm{~g}$ and then centrifuged at $4000 \mathrm{rpm}$ for $15 \mathrm{~min}$. The supernatant was decanted for determination of its solid content and the sediment was weighted. WAI and WSI were calculated as:

$$
\text { WAI }=\frac{\text { Weight of sediment }}{\text { Weight of dry solids }}, \quad \text { WSI }=\frac{\text { Weight of dissolved solids in supernatant } \times 100}{\text { Weight of dry solids }}
$$

\subsubsection{Water Holding Capacity}

Approximately 5 grams of fine ground sample was weighed and allowed to rehydrate over night in excess water (7:1). After draining, it was reweighed and WHC was calculated as [20]:

$$
\text { WHC }=\frac{\text { Weight of wet extrudate powder }- \text { Weight of dry extrudate powder } \times 10}{\text { Weight of dry extrudate powder }}
$$

\subsection{Sensory Evaluation}

The sensory assessments were conducted by 100 untrained Iranian panellists, who stay in Hyderabad, India (adult female and male). The use of adult instead of the target recipients, children, was necessary because of their ability to objectively evaluate the sensory characteristics of the formulations. Samples were coded. The panellists were provided with a glass of water and, instructed to rinse and swallow water between samples. They were given written instructions and asked to evaluate the products for colour, flavour, texture and overall acceptability using nine-point hedonic scale $(1=$ dislike extremely to $9=$ like extremely) [21].

\subsection{Statistical Analysis}

The data were analyzed by computer using Statistical Package for Social Science (SPSS Inc., Chicago IL, Version 11.5). The analysis was carried out in triplicate for all determinations. The mean and standard deviation (SD) of the triplicate analyses were calculated. Quantitative variables were analyzed by one-way ANOVA. When the one-way ANOVA results were significant, the Bonferroni test was performed to determine whether significant differences existed between different variables means. The significance of the differences was defined as $\mathrm{p}<0.05$.

\section{Results}

Chemical composition different namely moisture content, macronutrients contents (such as protein, fat and carbohydrates) ash and crude fiber of different extruded formulas are presented in the Table 2.

Moisture content of extruded formula E $(5.7 \pm 0.1)$ was higher than others, while in the extruded formula C (3.9 \pm 0.5$)$ it was in the lowest content $(\mathrm{p}<0.05)$. Comparison between moisture content of extruded formulas with A (control) showed an increase in the moisture content of all extruded samples except in the extruded formula C.

Chemical analysis of data showed: the protein contents of extruded formulas B, D and followed by F were in the highest values. The extruded formula A showed the lowest amount of protein. Extruded formula $\mathrm{E}$ had the highest amount of fat while it was in the lowest amount in the extruded formulas B, D and F. It is clear in the Table 2 that, the carbohydrate in the extruded formula A was significantly higher than others $(p<0.05)$. The lowest amount of ash and crude fiber was observed in the formula A. Content of energy in the extruded formulas E, F and C were significantly higher than control sample (A).

Micronutrients contents of different extruded products are presented in the Table 3. As it shown in the table, mean and standard deviation of Fe content in the extruded formula B, D, and F were in the higher ranks among other extruded formulas. Mean calcium content in the extruded formulas $\mathrm{C}, \mathrm{E}$ and $\mathrm{F}$ were in the highest amounts. Magnesium content in the extruded formulas B, D and F were higher than others. Cu content in the extruded extruded formula C, D, B and F were higher than others. Manganese content in the extruded formulas B, C and F were higher than others. Zinc contents in the extruded formulas B, D and F were higher than others.

The functional properties of six extruded formulas are presented in the Table 4. Tap density in the extruded formula A was in the highest amount $(0.56 \pm 0.04)$. Tap density in the extrude formulas B and D were same and 
Table 2. Mean $( \pm \mathrm{SD})$ macronutrient composition of the extruded products (g/100g).

\begin{tabular}{cccccccc}
\hline Product & Moisture (\%) & Protein $(\mathrm{g})$ & Fat $(\mathrm{g})$ & Carbohydrate $(\mathrm{g})$ & Ash $(\mathrm{g})$ & Crude fiber $(\mathrm{g})$ & Energy $($ Kcal) \\
\hline A & $4.5 \pm 0.4 \mathrm{a}$ & $11.00 \pm 0.1 \mathrm{a}$ & $3.6 \pm 0.7 \mathrm{a}$ & $66.2 \pm 0.4 \mathrm{a}$ & $1.50 \pm 0.1 \mathrm{a}$ & $2.70 \pm 0.4 \mathrm{a}$ & $341.2 \pm 1.4 \mathrm{ad}$ \\
B & $4.8 \pm 0.7 \mathrm{a}$ & $15.14 \pm 0.4 \mathrm{~b}$ & $2.4 \pm 0.5 \mathrm{~b}$ & $63.4 \pm 0.6 \mathrm{~b}$ & $2.08 \pm 0.3 \mathrm{~b}$ & $2.86 \pm 0.6 \mathrm{~b}$ & $335.8 \pm 0.9 \mathrm{~b}$ \\
C & $3.9 \pm 0.5 \mathrm{~b}$ & $13.06 \pm 0.6 \mathrm{c}$ & $3.69 \pm 0.4 \mathrm{a}$ & $65.3 \pm 0.4 \mathrm{c}$ & $1.97 \pm 0.5 \mathrm{~b}$ & $2.89 \pm 0.2 \mathrm{~b}$ & $346.6 \pm 0.15 \mathrm{c}$ \\
D & $4.5 \pm 0.1 \mathrm{a}$ & $15.15 \pm 0.8 \mathrm{~b}$ & $2.38 \pm 0.3 \mathrm{~b}$ & $63.3 \pm 0.6 \mathrm{~b}$ & $2.01 \pm 0.2 \mathrm{~b}$ & $2.84 \pm 0.5 \mathrm{cb}$ & $335.2 \pm 0.7 \mathrm{~b}$ \\
E & $5.7 \pm 0.1 \mathrm{c}$ & $12.72 \pm 0.2 \mathrm{a}$ & $3.89 \pm 0.1 \mathrm{a}$ & $65.5 \pm 0.7 \mathrm{c}$ & $1.94 \pm 0.1 \mathrm{c}$ & $2.88 \pm 0.1 \mathrm{~b}$ & $347.8 \pm 0.9 \mathrm{~cd}$ \\
F & $4.9 \pm 0.3 \mathrm{a}$ & $14.82 \pm 0.2 \mathrm{~b}$ & $3.04 \pm 0.6 \mathrm{c}$ & $64.4 \pm 0.3 \mathrm{~d}$ & $2.00 \pm 0.1 \mathrm{~b}$ & $2.89 \pm 0.5 \mathrm{~b}$ & $344.2 \pm 1.1 \mathrm{~d}$ \\
F. Results & $0.02^{*}$ & $0.01^{*}$ & $0.02^{*}$ & $0.05^{*}$ & $0.04^{*}$ & $0.03^{*}$ & $0.05^{*}$ \\
\hline
\end{tabular}

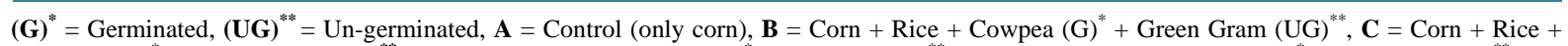
Chickpea $(\mathrm{G})^{*}+$ Green Gram $(\mathrm{UG})^{* *}, \mathbf{D}=$ Corn + Rice + Cowpea $(\mathrm{G})^{*}+$ Cowpea $(\mathrm{UG})^{* *}, \mathbf{E}=$ Corn +Rice + Chickpea $(\mathrm{G})^{*}+$ Chickpea $(\mathrm{UG})^{* *}, \mathbf{F}=$ Corn + Rice + Chickpea $(\mathrm{G})^{*}+$ Cowpea $(\mathrm{G})^{*}+$ Chickpea $(\mathrm{UG})^{* *}+$ Cowpea $(\mathrm{UG})^{* * *}+$ Green Gram (UG) ${ }^{* *}$; $^{*}$ Significant at $5 \%$ level; Note: Different superscript in columns indicate significant different at $5 \%$ level as shown by post hoc Bonferroni.

Table 3. Mean ( \pm SD) micronutrients contents of extruded products $(\mathrm{mg} / 100 \mathrm{mg})$.

\begin{tabular}{ccccccc}
\hline Product & Fe (mg) & Ca $(\mathrm{mg})$ & Mg (mg) & Cu (mg) & Mn (mg) \\
\hline A & $2.80 \pm 0.4 \mathrm{a}$ & $10.0 \pm 0.4 \mathrm{a}$ & $139.00 \pm 1.2 \mathrm{a}$ & $0.46 \pm 0.5 \mathrm{a}$ & $0.78 \pm 0.2 \mathrm{a}$ & $1.6 \pm 0.1 \mathrm{a}$ \\
B & $4.43 \pm 0.3 \mathrm{~b}$ & $35.8 \pm 0.3 \mathrm{~b}$ & $154.85 \pm 0.9 \mathrm{~b}$ & $0.54 \pm 01 \mathrm{~b}$ & $1.01 \pm 0.3 \mathrm{~b}$ & $2.6 \pm 0.5 \mathrm{~b}$ \\
C & $3.21 \pm 0.6 \mathrm{c}$ & $73.3 \pm 0.63$ & $133.50 \pm 0.5 \mathrm{c}$ & $0.64 \pm 0.3 \mathrm{c}$ & $1.09 \pm 0.1 \mathrm{c}$ & $2.0 \pm 0.3 \mathrm{c}$ \\
D & $4.62 \pm 0.2 \mathrm{~b}$ & $33.5 \pm 0.2 \mathrm{~b}$ & $158.95 \pm 1.3 \mathrm{~d}$ & $0.57 \pm 0.2 \mathrm{~b}$ & $0.79 \pm 0.1 \mathrm{a}$ & $2.6 \pm 0.4 \mathrm{~b}$ \\
E & $3.22 \pm 0.1 \mathrm{c}$ & $77.0 \pm 0.6 \mathrm{~d}$ & $134.10 \pm 0.5 \mathrm{c}$ & $0.40 \pm 0.3 \mathrm{~d}$ & $0.66 \pm 0.4 \mathrm{~d}$ & $2.0 \pm 0.2 \mathrm{c}$ \\
F & $4.40 \pm 0.5 \mathrm{~b}$ & $69.6 \pm 0.1 \mathrm{e}$ & $148.15 \pm 0.7 \mathrm{~d}$ & $0.52 \pm 0.1 \mathrm{~b}$ & $1.00 \pm 0.1 \mathrm{~b}$ & $2.4 \pm 0.1 \mathrm{~b}$ \\
F. Results & $0.05^{*}$ & $0.003^{*}$ & $0.001^{*}$ & $0.01^{*}$ & $0.04^{*}$ \\
\hline
\end{tabular}

$(\mathbf{G})^{*}=$ Germinated, $(\mathbf{U G})^{* *}=$ Un-germinated, $\mathbf{A}=$ Control (only corn), $\mathbf{B}=$ Corn + Rice + Cowpea $(\mathrm{G})^{*}+$ Green Gram $(\mathrm{UG})^{* * *}, \mathbf{C}=$ Corn + Rice + Chickpea $(\mathrm{G})^{*}+$ Green Gram (UG) ${ }^{* *}, \mathbf{D}=$ Corn + Rice + Cowpea $(\mathrm{G})^{*}+$ Cowpea $(\mathrm{UG})^{* *}, \mathbf{E}=$ Corn +Rice + Chickpea $(\mathrm{G})^{*}+$ Chickpea $(\mathrm{UG})^{* * *}, \mathbf{F}=$ Corn + Rice + Chickpea (G) ${ }^{*}+$ Cowpea $(G)^{*}+$ Chickpea (UG) ${ }^{* *}+$ Cowpea (UG) ${ }^{* *}+$ Green Gram (UG) ${ }^{* *}$; ${ }^{*}$ Significant at $5 \%$ level; Note: Different superscript in columns indicate significant different at $5 \%$ level as shown by post hoc Bonferroni.

followed by F formula $(0.46 \pm 0.06,0.46 \pm 0.01$ and $0.47 \pm 0.05)$. The true density in the extruded formula A was significantly higher than others $(\mathrm{p}<0.05)$. Bulk density in the formula A was significantly less in the formula A3 while extrude formula C, showed the highest amount $(\mathrm{p}<0.05)$. Finding showed that WHC in the extrude formula B3 and D were same and it was significantly lower than others formula, and WHC value in the formula A was in the highest amount $(\mathrm{p}<0.05)$. WSI in the extrude formula B and A were same and in the highest amounts than others, while it was in the lowest amount in the extrude formula A $(0.45 \pm 0.03 ; 0.45 \pm$ 0.02 vs. $0.30 \pm 0.01 ; \mathrm{p}<0.05)$. The extruded formula A showed an increase in the WAI $(4.7 \pm 0.04)$, than other formulas $(\mathrm{p}<0.05)$ (Table 4).

Averages sensory properties (colour, flavour, texture and overall acceptability) of six extruded products are presented in the Table 5 . The results revealed that the mean scores of sensory evaluation extruded products $\mathrm{F}$ were significantly higher than other extruded formulas $(\mathrm{p}<0.05)$.

\section{Discussion}

Although mineral elements represent a minor portion of the composition of foods, they play major roles in food chemistry and nutrition. Minerals are classified as macro- and micro-minerals. Macro-minerals include calcium, phosphorous, sodium, potassium and chloride. Of these, calcium and phosphorus are needed in large amounts, while the rest are needed in smaller amounts. Micro-minerals include magnesium, manganese, zinc, iron, copper, molybdenum, selenium, iodine, cobalt and chromium, which are needed in minute amounts. Extrusion cooking generally affects macromolecules. Smaller molecules may be impacted upon by either the extrusion process it self or by changes in larger molecules, which in turn affect other compounds present in the food. Despite the importance of minerals for health, relatively few studies have examined mineral stability during extrusion because they are stable in other food processes [22]. Minerals are heat stable and unlikely to become lost in the steam distillate at the die. Extrusion can improve the absorption of minerals by reducing other factors that inhibit absorption.

The functional properties of six extruded formulas are presented in the Table 4. Tap density in the extruded formula A was in the highest amount $(0.56 \pm 0.04)$. Tap density in the extrude formulas B and D were same and followed by F formula $(0.46 \pm 0.06,0.46 \pm 0.01$ and $0.47 \pm 0.05)$ (Table $4 ; \mathrm{p}<0.05)$. Analysis of data showed tap density in the extrude formulas namely B, D, F that contain higher protein and low carbohydrate were lower 
Table 4. Functional properties of six extrude formula (tap density, true density and bulk density, WHC, WSI, WAI).

\begin{tabular}{ccccccc}
\hline Extrude Formula & Tap Density $(\mathrm{g} / \mathrm{cc})$ & True Density $\left(\mathrm{cm}^{3}\right)$ & Bulk Density $\left(\mathrm{cm}^{3}\right)$ & WHC (\%) & WSI (\%) & WAI (\%) \\
\hline A & $0.56 \pm 0.04 \mathrm{a}$ & $0.74 \pm 0.06 \mathrm{a}$ & $0.16 \pm 0.01 \mathrm{a}$ & $344 \pm 0.5 \mathrm{a}$ & $0.30 \pm 0.01 \mathrm{a}$ & $4.7 \pm 0.04 \mathrm{a}$ \\
B & $0.46 \pm 0.06 \mathrm{~b}$ & $0.69 \pm 0.03 \mathrm{a}$ & $0.20 \pm 0.05 \mathrm{bc}$ & $305 \pm 0.4 \mathrm{~b}$ & $0.45 \pm 0.03 \mathrm{~b}$ & $4.0 \pm 0.05 \mathrm{~b}$ \\
C & $0.50 \pm 0.02 \mathrm{~b}$ & $0.70 \pm 0.06 \mathrm{ab}$ & $0.23 \pm 0.05 \mathrm{bc}$ & $320 \pm 0.7 \mathrm{c}$ & $0.36 \pm 0.07 \mathrm{c}$ & $4.5 \pm 0.08 \mathrm{c}$ \\
D & $0.46 \pm 0.01 \mathrm{c}$ & $0.69 \pm 0.03 \mathrm{a}$ & $0.18 \pm 0.08 \mathrm{~b}$ & $305 \pm 0.1 \mathrm{~b}$ & $0.45 \pm 0.02 \mathrm{~b}$ & $4.1 \pm 0.04 \mathrm{~b}$ \\
E & $0.52 \pm 0.08 \mathrm{~d}$ & $0.71 \pm 0.02 \mathrm{~b}$ & $0.21 \pm 0.03 \mathrm{bc}$ & $318 \pm 0.3 \mathrm{~b}$ & $0.34 \pm 0.05 \mathrm{c}$ & $4.3 \pm 0.06 \mathrm{c}$ \\
F & $0.47 \pm 0.05 \mathrm{~d}$ & $0.70 \pm 0.05 \mathrm{~b}$ & $0.22 \pm 0.04 \mathrm{ce}$ & $315 \pm 0.7 \mathrm{~d}$ & $0.42 \pm 0.09 \mathrm{~d}$ & $4.3 \pm 0.01 \mathrm{~b}$ \\
F. Results & $0.001^{*}$ & $0.008^{*}$ & $0.004^{*}$ & $0.01^{*}$ & $0.003^{*}$ & $0.001^{*}$ \\
\hline
\end{tabular}

$(\mathbf{G})^{*}=$ Germinated, $(\mathbf{U G})^{* * *}=$ Un-germinated, A = Control (only Corn), $\mathbf{B}=$ Corn + Rice + Cowpea $(\mathrm{G})^{*}+$ Green Gram $(\mathrm{UG})^{* *}, \mathbf{C}=$ Corn + Rice + Chickpea $(\mathrm{G})^{*}+$ Green Gram (UG) ${ }^{* *}, \mathbf{D}=$ Corn + Rice + Cowpea $(\mathrm{G})^{*}+$ Cowpea $(\mathrm{UG})^{* * *}, \mathbf{E}=$ Corn + Rice + Chickpea $(\mathrm{G})^{*}+$ Chickpea $(\mathrm{UG})^{* *}, \mathbf{F}=$ Corn + Rice + Chickpea $(G)^{*}+$ Cowpea $(G)^{*}+$ Chickpea $(U G)^{* *}+$ Cowpea $(U G)^{* * *}+$ Green Gram (UG) ${ }^{* *}$; Significant at $5 \%$ level; Note: Different superscript in columns indicate significant different at $5 \%$ level as shown by post hoc Bonferroni.

Table 5. Mean $( \pm \mathrm{SD})$ of sensory properties of six extruded formulas.

\begin{tabular}{ccccc}
\hline Properties Products & Colour & Flavour & Texture & Overall Acceptability \\
\hline A & $6.2 \pm 1.3 \mathrm{a}$ & $7.7 \pm 0.9 \mathrm{a}$ & $8.3 \pm 0.8 \mathrm{a}$ & $7.4 \pm 0.9 \mathrm{a}$ \\
B & $5.9 \pm 1.2 \mathrm{~b}$ & $6.8 \pm 1.1 \mathrm{~b}$ & $6.7 \pm 1.2 \mathrm{bd}$ & $6.5 \pm 1.4 \mathrm{~b}$ \\
C & $6.2 \pm 1.4 \mathrm{c}$ & $7.3 \pm 1.5 \mathrm{c}$ & $7.2 \pm 1.5 \mathrm{c}$ & $6.9 \pm 1.5 \mathrm{c}$ \\
D & $5.5 \pm 1.8 \mathrm{a}$ & $6.5 \pm 1.5 \mathrm{~b}$ & $6.2 \pm 1.0 \mathrm{~b}$ & $6.1 \pm 1.9 \mathrm{~d}$ \\
E & $6.6 \pm 1.1 \mathrm{ad}$ & $7.3 \pm 1.6 \mathrm{~b}$ & $8.0 \pm 1.2 \mathrm{~d}$ & $7.3 \pm 1.3 \mathrm{~d}$ \\
F & $7.2 \pm 1.9 \mathrm{e}$ & $8.0 \pm 1.8 \mathrm{~d}$ & $8.5 \pm 1.0 \mathrm{e}$ & $7.9 \pm 1.8 \mathrm{e}$ \\
F. Results & $0.04^{*}$ & $0.01^{*}$ & $0.02^{*}$ & $0.05^{*}$ \\
\hline
\end{tabular}

$(\mathbf{G})^{*}=$ Germinated, $(\mathbf{U G})^{* *}=$ Un-germinated, $\mathbf{A}=$ Control (only Corn), $\mathbf{B}=$ Corn + Rice+ Cowpea $(\mathrm{G})^{*}+$ Green Gram $(\mathrm{UG})^{* *}, \mathbf{C}=$ Corn + Ice + Chickpea $(\mathrm{G})^{*}+$ Green Gram $(\mathrm{UG})^{* *}, \mathbf{D}=$ Corn + Rice + Cowpea $(\mathrm{G})^{*}+$ Cowpea $(\mathrm{UG})^{* *}, \mathbf{E}=$ Corn + Rice + Chickpea $(\mathrm{G})^{*}+$ Chickpea $(\mathrm{UG})^{* *}, \mathbf{F}=$ Corn + Rice + Chickpea $(G)^{*}+$ Cowpea $(G)^{*}+$ Chickpea (UG) ${ }^{* *}+$ Cowpea $(U G)^{* *}+$ Green Gram (UG) ${ }^{* *}$; ${ }^{*}$ Significant at $5 \%$ level; Note: Different superscript in columns indicate significant different at $5 \%$ level as shown by post hoc Bonferroni.

than those formula with low content protein (A). Similar types results reported by Deshpande and Poshadri [20], Ruiz-Ruiz et al. [23]. The true density in the formula A3 was in the highest amount while in the formula B and $\mathrm{D}$; it was in the lowest amounts $(0.69 \pm 0.03)$. The true density in the extruded formula A was significantly higher than others $(\mathrm{p}<0.05)$.

The bulk density in the formula A was significantly less in the formula A3 while extrude formula C, showed the highest amount $(\mathrm{p}<0.05)$ (Table 4). Although increase in the protein content is a reason for decreasing of the bulk density in extruded products but our finding showed an increase in the bulk density in the extruded products with higher content of protein. It may be related to their content of their crude fiber, because it was higher in these products, Ruiz-Ruiz et al. [23]; Singh et al. [24] and Deshpande and Poshadri [20] reported the crude fiber has effect on the bulk density.

Analysis of data showed that WHC in the extrude formula B3 and D were same and it was significantly lower than others formula, and WHC value in the formula A was in the highest amount $(\mathrm{p}<0.05)$ (Table 4). Our finding showed the WHC in the extruded formula A was higher than other formula; this could be due to higher level of corn starch in its content. Similar results were observed by Gamalth and Ganeshranee [25].

The Water Solubility Index (WSI) is related to the quantity of water soluble molecules, and is associated to dextrinization. In other words, WSI can be used as an indicator of the degradation of molecular compounds, and measures the starch degradation resulted from extrusion cooking [26] [27]. Recently, WSI was used as an indicator for evaluating the degree of cooking in extruded products [28].

WSI in the extrude formula B and A were same and in the highest amounts than others, while it was in the lowest amount in the extrude formula $\mathrm{A}(0.45 \pm 0.03 ; 0.45 \pm 0.02$ vs. $0.30 \pm 0.01 ; \mathrm{p}<0.05)$. The water solubility index of the extruded formulas increased when cowpea and chickpea flour were as a part of combination with ratio more than $10 \%$. The water absorption index of the extrudates increased with increase of chick pea and Cow pea flours in the composite flour. These results are in conformity with the observations made by Gamalth and Ganeshranee [25].

Value of WAI in the extrude formula B $(4.0 \pm 0.05)$ and D $(4.1 \pm 0.04)$ showed decrease, that followed by the extrude formula $\mathrm{E}$ and $\mathrm{F}$. The extruded formula A showed an increase in the WAI $(4.7 \pm 0.04)$, than other formulas $(\mathrm{p}<0.05)$. The water absorption index is the amount of water that absorbed by starch and can be used as 


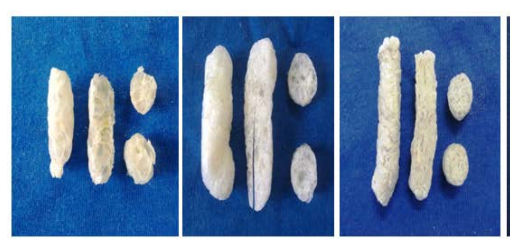

(a) (b)

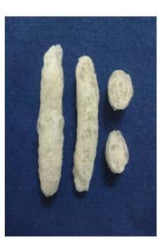

(d)

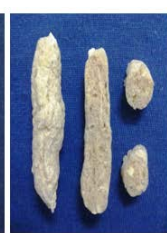

(e)

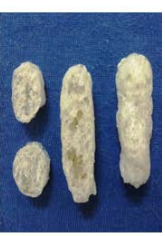

(f)

Figure 1. Figures of six extruded products from (a) to (f) (left to right).

an index of gelatinization [28]. The gelatinization is the conversion of raw starch into a cooked and digestible material by the application of water and heat. And also, gelatinization is one of the important effects that extrusion has on the starch component of foods. Our finding showed that the maximum WAI value was higher in the extruded formula A and it may be related to its starch content. WHC was in the highest amount in the extruded formula A, while WSI in the extruded formula B, D and followed by F were in the highest amount (p $<0.05)$.

Comparison among the averages of sensory properties (namely colour, flavour, texture and overall acceptability) of six extruded products (see Figure 1) showed that, the mean scores of sensory evaluation extruded product F were significantly better in colour (7.2 \pm 1.9$)$, flavor $(8.0 \pm 1.8)$, texture $(8.5 \pm 1.0)$, and overall acceptability $(7.9 \pm 1.8)$ than others (Table 5). The results indicated that, the composite flour $F$ that contain; corn, rice, cowpea (germinated), chickpea (germinated), green gram, cowpea (un-germinated ), chickpea (un-germinated) in the ratios of 55:10:10:10:5:5:5 respectively, could be used to produce quality extruded with acceptable sensory properties.

\section{Conclusion}

Extrusion cooking is an ideal method for manufacturing a number of food products from snacks and breakfast cereals to baby foods. Extrusion also permits the utilization and co-processing of various by-products. As a complex multivariate process, extrusion requires careful control if product quality is to be maintained. The present study revealed that, composite flour (corn, rice, cowpea (germinated), chickpea (germinated), green gram (mung), cowpea (un-germinated), chickpea (un-germinated) in the ratios of 55:10:10:10:5:5:5 respectively) could be used to produce quality extruded.

\section{Suggestion}

There are many areas that require further research regarding extrusion and nutrition. Very few have been published on the effects of extrusion on phytochemicals and other healthful food components. Future research may be focused on the relationships between compositional changes on product quality — both nutritional and sensory aspects, and the effects of interactions between complex extruder conditions on nutrient retention.

\section{Acknowledgements}

The authors would like to appreciate from Dr Singh head of laboratory Osmania University and his colleagues for their support and cooperation. First author have special thanks from the University of Medical Science and Health Services of Zahedan, Iran for his supporting to conduct this investigation at Osmina University, Hyderabad, India.

\section{References}

[1] Brown, K.H. (2003) Diarrhea and Malnutrition. Journal of Nutrition, 133, 328S-332S.

[2] FAO (2001) Targeting for Nutrition Improvement. Resources for Advancing Well Being. Food and Nutrition Division, Rome.

[3] Ijarotimi, O.S. and Keshinro, O.O. (2012) Formulation and Nutritional Quality of Infant Formula Produced from Germinated Popcorn, Bambara Groundnut and African Locust Bean Flour. Journal of Microbiology, Biotechnology and Food Sciences, 1, 1358-1388.

[4] Nemer, L., Gelband, H. and Jha, P. (2001) Commission on Macroeconomics and Health. The Evidence Base for Interventions to Reduce Malnutrition in Children under Five and School Age Children in Low- and Middle-Income Countries. CMH Working Paper No WG5, World Health Organization, Geneva, 11. 
[5] Muller, O., Garenne, M., Kouyate, B. and Becher, H. (2003) The Association between Protein-Energy Malnutrition, Malaria Morbidity and All-Cause Mortality in West African Children. Tropical Medicine \& International Health, 8, 507-511. http://dx.doi.org/10.1046/j.1365-3156.2003.01043.x

[6] FAO (2004) Undernourishment around the World. In: The State of Food Insecurity in the World, FAO, Rome.

[7] Federal Ministry of Health, Nutrition Division (2005) Policy—National Policy on Infant and Young Child Feeding in Nigeria.

[8] Black, R.E., Morris, S.S. and Bryce, J. (2003) Where and Why Are 10 Million Children Dying Every Year? Lancet, 361, 2226-2234. http://dx.doi.org/10.1016/S0140-6736(03)13779-8

[9] Alozie, Y.E., Iyam, M.A., Lawal, O., Udofla, U. and Ani, I.F. (2009) Utilization of Bambara Ground Flour Blends in Bread Produce Production. Journal of Food Technology, 7, 111-114.

[10] Eka, B.E., Abbey, B.W. and Akaninwor, J.O. (2010) Nutritional Evaluation of Some Traditional Weaning Foods from Akwa Ibom State, Nigeria. Nigerian Journal of Biochemistry and Molecular Biology, 25, 65-72.

[11] Bhattacharya, J., Currie, J. and Haider, S. (2004) Poverty, Food Insecurity, and Nutritional Outcomes in Children and Adults. Journal Health Economic, 23, 839-862. http://dx.doi.org/10.1016/j.jhealeco.2003.12.008

[12] Anigo, K.M., Ameh, D.A., Ibrahim, S. and Danbauchi, S.S. (2007) Microbiological Analyses of Commonly Used Local Complementary Foods in North Western Nigeria. Journal of Medical Sciences, 7, 875-879. http://dx.doi.org/10.3923/jms.2007.875.879

[13] Muhimbula, H.S., Issa-Zacharia, A. and Kinabo, J. (2011) Formulation and Sensory Evaluation of Complementary Foods from Local, Cheap and Readily Available Cereals and Legumes in Iringa, Tanzania. African Journal of Food Science, 5, 26-31.

[14] Jean, I.J., Work. R, Camire, E., Briggs, J., Barnett, A.H. and Bushway, A.A. (1996) Selected Properties of Extruded Potato and Chicken Meat. Journal of Food Sciences, 61, 783-789. http://dx.doi.org/10.1111/j.1365-2621.1996.tb12203.x

[15] Toft, G. (1979) Snack Foods: Continuous Processing Techniques. Cereal Foods World, 24, 142-143.

[16] Stojceska, V., Ainsworth, P., Plunkett, A., Ibanoglu, E. and Ibanoglu, S. (2008) Cauliflower By-Products as a New Source of Dietary Fibre, Antioxidants and Proteins in Cereal Based Ready-to-Eat Expanded Snacks. Journal of Food Engineering, 87, 554-563. http://www.sciencedirect.com

[17] Association of Official Analytical Chemists (AOAC) (2005) Official Methods of Analysis of the AOAC International. 18th Edition, Gaithersburg. http://www.scribd.com/doc/131064441/AOAC-2005

[18] Udo, E.J. and Oguwele, J.A. (1986) Laboratory Manual for the Analysis of Soil, Plants and Water Samples. 3rd Edition, Department of Crop Production, University of Ilorin, Ilorin, 131-152.

[19] Anderson, R.A. (1982) Water Absorption and Solubility and Amylograph Characteristics of Roll-Cooked Small Grain Products. Cereal Chemistry, 59, 265-269.

[20] Deshpande, H.W. and Poshadri, A. (2011) Physical and Sensory Characteristics of Extruded Snacks Prepared from Foxtail Millet Based Composite Flours. International Food Research Journal, 18, 751-756.

[21] Meilgaard, M., Civille, G.V. and Carr, B.T. (1999) Sensory Evaluation Techniques. 3rd Edition, CRC Press, Boca Raton.

[22] Camire, M.E., Camire, A. and Krumhar, K. (1990) Chemical and Nutritional Changes in Foods during Extrusion. CRC Reviews Food Science Nutrition, 30, 35-45.

[23] Ruiz-Ruiz, J., Martínez-Ayala, A., Drago, S.R., González, R.J., Betancur-Ancona, D. and Chel-Guerrero, L. (2008) Extrusion of a Hard-to-Cook Bean (Phaseolus vulgaris L.) and Quality Protein Maize (Zea mays L.) Flour Bend. Food Science and Technology, 41, 99-807.

[24] Singh, R., Singh, G. and Chauhan, G.S. (1996) Effect of Incorporation of Defatted Soy Flour on the Quality of Biscuits. Food Science and Technology, 33, 355-357.

[25] Gamalth, S. and Ganesharanee, R. (2009) Extruded Products with Fenugreek (Trigonellagraecium) Chick Pea and Rice: Physical Properties, Sensory Acceptability and Glycemic Index. Journal of Food Engineering, 90, 45-52.

[26] Colonna, P., Tayeb, J. and Mercier, C. (1989) Extrusion Cooking of Starch and Starchy Products. In: Mercier, C., Linko, C.P. and Harper, J.M., Eds., Extrusion Cooking, American Association of Cereal Chemists, Inc., St. Paul, 247-319.

[27] Ding, Q., Ainsworth, B., Plonkell, A., Tucker, G. and Marson, H. (2005) The Effect of Extrusion Conditions on the Physicochemical Properties and Sensory Characteristics of Rice-Based Expanded Snacks. Journal of Food Engineering, 66, 283-289. http://dx.doi.org/10.1016/j.jfoodeng.2004.03.019

[28] Anderson, R.A., Conway, H.F. and Peplinski, A.J. (1970) Gelatinization of Corn Grits by Roll and Extrusion Cooking. Starch-Stärke, 22, 130-135. http://dx.doi.org/10.1002/star.19700220408 
Scientific Research Publishing (SCIRP) is one of the largest Open Access journal publishers. It is currently publishing more than 200 open access, online, peer-reviewed journals covering a wide range of academic disciplines. SCIRP serves the worldwide academic communities and contributes to the progress and application of science with its publication.

Other selected journals from SCIRP are listed as below. Submit your manuscript to us via either submit@scirp.org or Online Submission Portal.
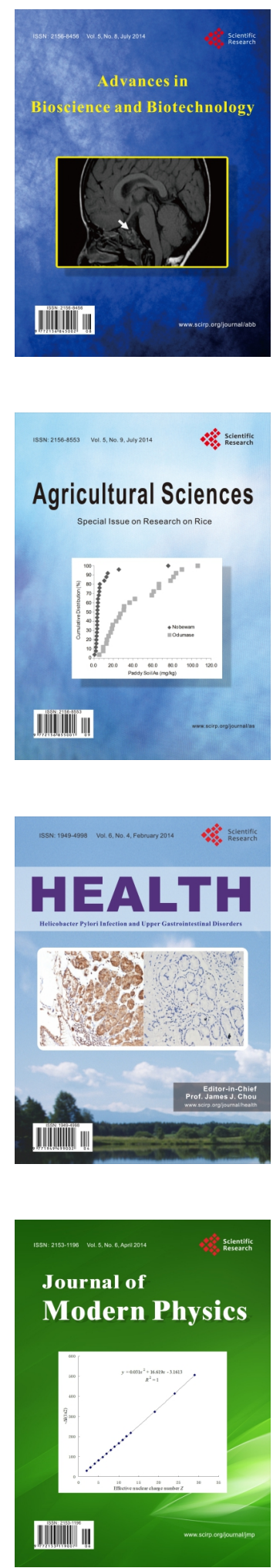
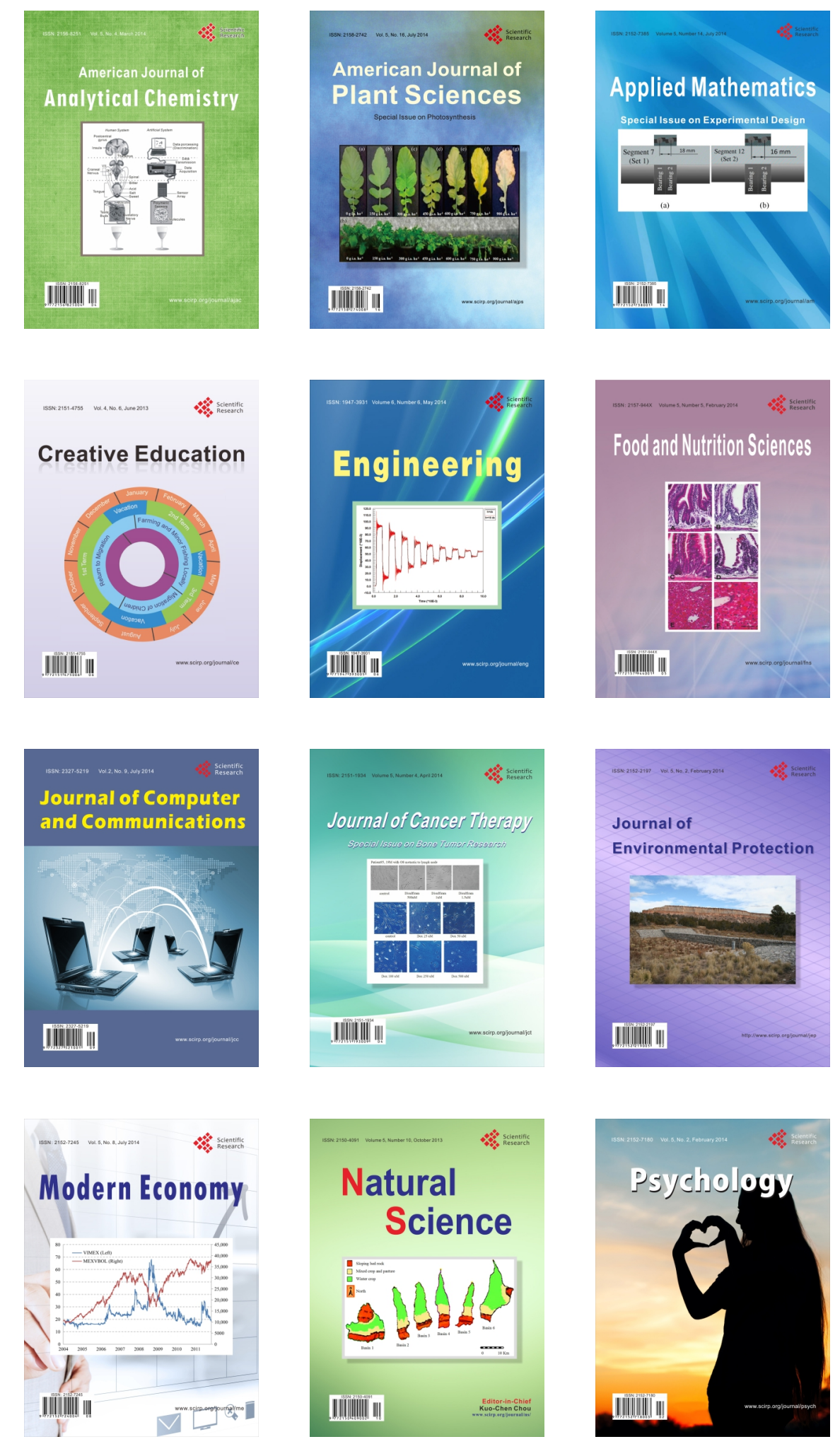